\title{
SENYAWA ANTIMAKAN TERHADAP Epilachna Sparsa DARI BATANG GAYAM (Inocarpus fagiferus Fosb.)
}

\author{
I M. Sukadana, S. R. Santi*, dan N. N. T. Hanayanthi \\ Program Studi Kimia, Fakultas Matematika dan Ilmu Pengetahuan Alam, Universitas Udayana \\ Jalan Kampus Unud-Jimbaran, Jimbaran-Bali, Indonesia \\ *Email: sr_santi@unud.ac.id
}

\begin{abstract}
ABSTRAK
Epilachna sparsa merupakan salah satu hama tanaman yang merusak lapisan epidermis di bawah daun, sehingga dapat mengakibatkan jaringan daun rusak dan hanya tersisa tulang daunnya. Gayam (Inocarpus fagiferus) merupakan salah satu species dari famili Legumineceae diduga mempunyai aktivitas insektisida. Penelitian ini bertujuan untuk mengisolasi dan mengidentifikasi golongan senyawa triterpenoid anti makan batang gayam (Inocarpus fagiferus Fosb.) terhadap larva Epilachna sparsa. Ekstraksi $1200 \mathrm{~g}$ batang gayam menghasilkan 17,82 g ekstrak kental metanol dengan aktivitas antimakan 60,74\% pada konsentrasi 5\% (b/v) yang selanjutnya dipisahkan dengan cara partisi sehingga diperoleh ekstrak n-heksana, etil asetat, dan air. Hasil uji aktivitas anti makan menunjukkan hanya ekstrak n-heksana yang aktif pada konsentrasi 3\%. Ekstrak nheksana selanjutnya diidentifikasi dengan uji fitokimia triterpenoid dan LC-MS/MS. Hasil identifikasi fitokimia menunjukkan ekstrak n-heksana positif mengandung senyawa triterpenoid. Analisis spektra massa dari puncakpuncak kromatogram hasil LC-MS/MS dengan software MassLynx V4.1 dan database Chemspider terhadap ekstrak n-heksana yang sebelumnya dimurnikan dengan metode SPE (Solid Phase Extraction) menggunakan eluen metanol dan diklorometana (DCM) diduga mengandung senyawa flavonol pyrogallol, sucrose 2,3,3',4',6pentaacetate, soyasaponin I, dan senyawa dengan berat molekul 685,225 g/mol yang tidak dapat diidentifikasi lebih lanjut karena tidak ada kemiripan dengan spektrum massa dengan database.
\end{abstract}

Kata kunci: antimakan, Epilachna sparsa, gayam, Inocarpus fagiferus Fosb., triterpenoid.

\begin{abstract}
Epilachna sparsa is one of the plant pests that damage the epidermal layer on the bottom side of the leaves, so it can lead to damage of leaf tissue and only the skeleton remains. Gayam (Inocarpus fagiferus) is one of the species of the Legumineceae family which has insecticide activity. This study aims to isolate and identify the antifeedant triterpenoid compound from stem of gayam (Inocarpus fagiferus Fosb.) against Epilachna sparsa larvae. Dried powder of $1200 \mathrm{~g}$ gayam stems produced $17.82 \mathrm{~g}$ of crude methanol extract with antifeedant activity of $60.74 \%$ at a concentration of $5 \%(\mathrm{w} / \mathrm{v})$ which was further separated by partition to obtain n-hexane, ethyl acetate, and water extracts. Extracts of n-hexane, ethyl acetate, and water at 5\% (w/v) concentration showed antifeedant activity of $46.74 \%, 18.09 \%$, and $8.31 \%$ respectively. Futhermore, the most active $\mathrm{n}$-hexane extract was identified by phytochemical tests and LC-MS/MS. The phytochemical test showed n-hexane extract contains triterpenoid compounds. The mass spectra from LC-MS/MS chromatogram peaks with MassLynx V4.1 software and Chemspider database for n-hexane extracts which were previously purified by SPE (Solid method) Phase Extraction) using methanol and dichloromethane (DCM) eluents show the presence of components of flavonol pyrogallol, sucrose 2,3,3 ', 4', 6-pentaacetate, soyasaponin I, and a compound with a molecular weight of $685,225 \mathrm{~g} / \mathrm{mol}$ which cannot be identified further because there is no match spectra with the database.
\end{abstract}

Keywords: antifeedant, Epilachna sparsa, gayam, Inocarpus fagiferus Fosb., triterpenoid.

\section{PENDAHULUAN}

Hama adalah organisme pengganggu tanaman yang dapat menimbulkan kerusakan fisik pada tanaman sehingga produktivitas tanaman menurun. Pengendalian hama tanaman biasanya menggunakan pestisida sintetik oleh karena bahan ini mudah didapat, praktis dan efektif. Penggunaan pestisida sintetik dalam frekuensi tinggi serta tanpa 
pengawasan dari pihak yang berwenang akan berdampak buruk terhadap hama target maupun lingkungan (Dadang, 2008). Alternatif untuk mengurangi penggunaan dan dampak yang kurang baik dari pestisida sintetik adalah memanfaatkan pestisida alami yang bersumber dari tumbuh-tumbuhan atau pestisda nabati. Pestisida nabati umumnya efektif terhadap hama target, cepat terurai, sehingga residunya tidak berdampak buruk pada lingkungan maupun produk pertanian, toksisitasnya relatif rendah terhadap hama non target seperti parasit dan predator hama lainnya (Ruslan dkk, 1989). Pestisida nabati antimakan dianggap memiliki prospek komersial yang lebih baik (Ruslan dkk, 1989) karena memiliki mode of action tidak membunuh, mengusir, atau menjerat tetapi hanya menghambat napsu makan dari hama (Haji dkk, 2012).

Senyawa antimakan banyak ditemukan pada berbagai jenis tumbuhan seperti dari famili Meliaceae, Solanaceae, Piperaceae, Legumineceae, Burseraceae, Astaceae, annonaceae dan sebagainya. Gayam (Inocarpus fagiferus) yang termasuk dalam famili Legumineceae diduga mempunyai aktivitas insektisida karena tidak ada hama dan penyakit utama yang dapat menyerang bagian batang dan daun tumbuhan ini, sekalipun bunga dan buah yang sedang tumbuh rentan terhadap lalat buah (Pauku, 2006). Senyawa antimakan banyak ditemukan pada senyawa golongan alkaloid, fenolat, terpenoid khususnya pada triterpenoid seperti volkesin, azadirachtin, digitoxin, withanolide $\mathrm{E}$, dan aginosid (Isman, 2002). Hasil uji pendahuluan menunjukkan batang gayam mempunyai aktivitas antimakan sebesar $60,74 \%$ pada konsentrasi $5 \%$ terhadap larva Epilachna sparsa, suatu bioindikator umum untuk penelusuran antimakan.

\section{MATERI DAN METODE}

\section{Bahan}

Batang gayam, daun labu, akuades, metanol, n-heksana, etil asetat, peraksi Liebermann-Burchard, diklorometana dan larva Epilachna sparsa sebagai bioindikator.

\section{Peralatan}

Gunting, blender, neraca analitik, spatula, kertas saring, corong, gelas ukur, corong pisah, labu ukur $10 \mathrm{~mL}$, klem, statif, gelas beker, pipet tetes, tabung reaksi, cawan petri, botol reagen, botol vial, kuas, kain kasa, penguap putar vakum (rotary vacuum evaporator), instrumen LCMS/MS (LC System ACQUITY UPL ® Hclass System; LC Coloum ACQUITY UPLC $®$ HSSC18 $1.8 \mu \mathrm{m} 2.1 \times 100$ $\mathrm{mm}$; Mass Spectrometer Xevo G2-SQTof (Water, USA).

\section{Cara Kerja}

Serbuk kering batang gayam sebanyak $1200 \mathrm{~g}$ diekstrak dengan cara maserasi menggunakan pelarut methanol sebanyak $12 \mathrm{~L}$. Ekstrak yang diperoleh diuapkan dengan penguap putar vakum (vacuum rotary evaporator) sehingga diperoleh ekstrak kental metanol yang selanjutnya diuji aktivitas antimakan terhadap bioindicator Epilachna sparsa. Ekstrak kental metanol dilarutkan menggunakan pelarut metanol:air (7:3) kemudian metanol diuapkan dan ekstrak air yang tersisa dipartisi berturut-turut dengan nheksana dan etil asetat. Ketiga ekstrak diuapkan sehingga diperoleh masing-masing ekstrak kental dan diuji aktivitas antimakan dengan menggunakan larva Epilachna sparsa. Ekstrak yang paling aktif diidentifikasi dengan LCMS/MS.

Uji aktivitas antimakan dilakukan dengan metode daun cakram pilihan (Schwinger et al, 1984). Ekstrak pada konsentrasi $1 \%(\mathrm{~b} / \mathrm{v}), 2 \%(\mathrm{~b} / \mathrm{v}), 3 \%(\mathrm{~b} / \mathrm{v})$, dan $5 \%(\mathrm{~b} / \mathrm{v})$ masing-masing dioleskan merata pada bagian belakang dari daun media uji pada bagian kiri sedangkan pada bagian kanan diolesi dengan pelarutnya sebagai kontrol, lalu pelarut dibiarkan menguap. Larva Epilachna sparsa yang telah dipuasakan selama empat jam diletakkan di atas daun media uji, kemudian diinkubasi pada suhu kamar selama 24 jam. Daun media uji diambil setelah 24 jam dan dilakukan perhitungan luas daun yang dikonsumsi oleh hewan uji.

\section{HASIL DAN PEMBAHASAN}

Hasil maserasi $1200 \mathrm{~g}$ serbuk kering batang gayam dengan metanol menghasilkan17,82 g ekstrak kental metanol yang berwarna coklat kehitaman. Hasil uji aktivitas antimakan terhadap larva Epilachna sparsa menunjukkan ekstrak kental metanol mempunyai aktivitas antimakan sebesar $60,74 \%$ pada konsentrasi $5 \%$ sehingga dapat 
dikembangkan sebagai pestisida nabati, karena suatu bahan dikatakan aktif sebagai antimakan jika memiliki aktivitas antimakan lebih besar atau sama dengan 25\% (Mikolajczak dan Weisleder, 1988). Hasil partisi ekstrak kental metanol yang sebelumnya dilarutkan dalam campuran metanol:air (7:3) dengan $150 \mathrm{~mL}$ - heksana dan $150 \mathrm{~mL}$ etil asetat berturut-turut menghasilkan 0,54 g ekstrak kental n-heksana, 0,52 g ekstrak kental etil asetat, dan 4,58 gekstrak kental air. Hasil uji aktivitas antimakan ketiga ekstrak dipaparkan pada Tabel 1.

Tabel 1. Hasil Uji Aktivitas Antimakan Ekstrak Metanol, N-Heksana, Etil Asetat, dan Air

\begin{tabular}{|c|c|c|c|c|c|c|c|}
\hline \multirow[t]{2}{*}{ No. } & \multirow[t]{2}{*}{ Ekstrak } & \multirow{2}{*}{$\begin{array}{c}\text { Konsentrasi } \\
(\%(\mathrm{~b} / \mathrm{v}))\end{array}$} & \multicolumn{4}{|c|}{ Aktivitas Antimakan (\%) } & \multirow{2}{*}{$\begin{array}{l}\text { Standar } \\
\text { Deviasi }\end{array}$} \\
\hline & & & Ulangan 1 & $\begin{array}{c}\text { Ulangan } \\
2\end{array}$ & Ulangan 3 & Rata- rata & \\
\hline 1 & Metanol & 5 & 55,56 & 60 & 66,67 & 60,74 & 5,59 \\
\hline \multirow[t]{4}{*}{2} & N-Heksana & 1 & 7,69 & 7,69 & 8,33 & 7,90 & 0,37 \\
\hline & & 2 & 20 & 20 & 22,22 & 20,74 & 1,28 \\
\hline & & 3 & 42,86 & 42,86 & 46,67 & 44,13 & 2,20 \\
\hline & & 5 & 42,86 & 47,37 & 50,00 & 46,74 & 3,61 \\
\hline 3 & Etil asetat & 5 & 14,28 & 20 & 20 & 18,09 & 3,30 \\
\hline 4 & Air & 5 & 6,67 & 7,14 & 1,11 & 8,31 & 2,44 \\
\hline
\end{tabular}

Tabel 2. Hasil Homogenitas dan Normalitas

\begin{tabular}{cccccc}
\hline & $1 \%$ & $2 \%$ & $3 \%$ & $5 \%$ & $\mathrm{P}^{*}$ \\
\hline Isolat & $7,90 \pm 0,37$ & $20,74 \pm 1,28$ & $44,13 \pm 2,20$ & $46,74 \pm 3,61$ & 0,087 \\
n-heksana & 0,000 & 0,000 & 0,000 & 0,712 & \\
$\mathrm{P}^{* *}$ & & & &
\end{tabular}

Tabel 3. Hasil Uji Duncan Aktivitas Antimakan Antar Konsentrasi

\begin{tabular}{cc}
\hline Konsentrasi & Mean \pm Standar Deviasi \\
\hline $1 \%$ & $7,90 \pm 0,36^{\mathrm{a}}$ \\
$2 \%$ & $20,74 \pm 1,28^{\mathrm{b}}$ \\
$3 \%$ & $44,13 \pm 2,19^{\mathrm{c}}$ \\
$5 \%$ & $46,74 \pm 3,61^{\mathrm{c}}$
\end{tabular}

Keterangan: angka-angka dalam tabel yang diikuti huruf yang sama, tidak berbeda signifikan

Data pada Tabel 1 menunjukkan hanya ekstrak n-heksana yang mempunyai aktivitas antimakan. Hasil analisis statistik menggunakan uji ANOVA dengan software IBM versi 23 ditunjukkan pada Tabel 2 dan Tabel 3 .
Data pada Tabel 2 menunjukkan bahwa ekstrak n-heksana pada semua konsentrasi menunjukkan hasil yang homogen $(\mathrm{P}>0,05)$ tetapi data yang berdistribusi normal $(\mathrm{P}>0,05)$ ditunjukkan hanya pada konsentrasi $5 \%$. Oleh 
karena tidak semua data terdistribusi normal maka dilakukan uji Duncan untuk mengetahui perbedaan antar konsentrasi seperti ditunjukkan pada Tabel 3.

Data Tabel 3 menunjukkan terdapat perbedaan yang signifikan antara konsentrasi $1 \%, 2 \%$ dan 3\%, tetapi tidak ada perbedaan yang signifikan antara konsentrasi 3\% dan 5\%. Dengan demikian ekstrak pada konsentrasi 3\% sudah mampu menghambat nafsu makan Epilachna sparsa. Komponen senyawa dalam ekstrak n-heksana diketahui dari hasil analisis LCMS/MS.

Ekstrak aktif n-heksana sebelum dianalisis dengan LCMS/MS dimurnikan terlebih dahulu dengan metode SPE (Solid
Phase Extraction) menggunakan kromatografi kolom dengan eluen metanol dan diklorometana (DCM). Ekstrak nheksana hasil pemisahan dengan metanol menghasilkan 3 kromatogram dengan waktu retensi berturut-turut: 1,308; 3,741 dan 9,726 menit sedangkan pemurnian ekstrak n-heksana dengan diklorometana menghasilkan 2 puncak dengan waktu retensi 1,234 menit dan 3,762 menit. Hasil analisis kromatogram yang dihasilkan melalui pendekatan iFit 97,38\% (kedekatan pembacaan oleh software masslynx) diduga mengandung senyawa seperti dipaparkan pada Tabel 4 di bawah ini.

Tabel 4. Hasil Analisis Ekstrak Aktif n-Heksana

\begin{tabular}{|c|c|c|c|c|c|c|c|c|}
\hline \multirow[b]{2}{*}{ No } & \multirow[b]{2}{*}{$\begin{array}{c}\text { Pemisahan } \\
\text { dengan } \\
\text { Pelarut }\end{array}$} & \multirow[b]{2}{*}{$\begin{array}{l}\text { Waktu } \\
\text { Retensi }\end{array}$} & \multicolumn{2}{|c|}{ Sebelum Terionisasi } & \multicolumn{2}{|c|}{ Terionisasi } & \multirow[b]{2}{*}{$\begin{array}{l}\text { iFit } \\
(\%)\end{array}$} & \multirow[b]{2}{*}{ Nama Senyawa } \\
\hline & & & $\begin{array}{l}\text { Rumus } \\
\text { Molekul }\end{array}$ & $\begin{array}{c}\text { Berat } \\
\text { Molekul } \\
(\mathrm{g} / \mathrm{mol})\end{array}$ & $\begin{array}{l}\text { Rumus } \\
\text { Molekul }\end{array}$ & $\begin{array}{c}\text { Berat } \\
\text { Molekul } \\
(\mathrm{g} / \mathrm{mol})\end{array}$ & & \\
\hline 1. & Metanol & 1,308 & $\mathrm{C}_{21} \mathrm{H}_{17} \mathrm{O}_{6}$ & 365,1025 & $\mathrm{C}_{21} \mathrm{H}_{16} \mathrm{O}_{6}$ & 364,0946 & 97,38 & $\begin{array}{c}\text { Flavonol } \\
\text { Pyrogallol }\end{array}$ \\
\hline 2. & Metanol & 3,741 & $\mathrm{C}_{22} \mathrm{H}_{33} \mathrm{O}_{16}$ & 553,1769 & $\mathrm{C}_{22} \mathrm{H}_{32} \mathrm{O}_{16}$ & 552,1690 & 99,99 & $\begin{array}{l}\text { Sucrose } 2,3,3,4,, 6- \\
\quad \text { Pentaacetate }\end{array}$ \\
\hline 3. & $\mathrm{M}$ & 9,726 & $\mathrm{C}$ & 943 & 0 & 942.5187 & 10 & Soyasaponin I \\
\hline 4. & DC & 234 & $\mathrm{C}_{2}$ & 685,2 & & - & 93,70 & 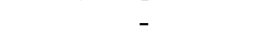 \\
\hline 5. & DCM & 3,762 & $\mathrm{C}_{22} \mathrm{H}_{33} \mathrm{O}_{16}$ & 553,1769 & $\mathrm{C}_{22} \mathrm{H}_{32} \mathrm{O}_{16}$ & 552,1690 & 94,93 & $\begin{array}{c}\text { Sucrose } 2,3,3,, 44^{\prime}, 6- \\
\text { Pentaacetate }\end{array}$ \\
\hline
\end{tabular}

Flavonol pyrogallol diduga dapat melindungi tanaman dari serangan hama dan penyakit (Sukarwa, 1983; Hanani, 2014) serta senyawa soyasaponin $I$ yang termasuk golongan saponin triterpenoid diduga bersifat antifeedant pada kutu, larva, kumbang, dan berbagai serangga lainnya dengan menghambat system pernafasan serangga (Vincent, 1995).

Mekanisme kerja senyawa penghambat aktivitas antimakan (antifeedant) belum diketahui secara pasti, meskipun ada yang menyebutkan terjadinya interaksi beberapa senyawa seperti senyawa terpenoid dengan reseptor sensor serangga atau larva (Gershenzon, 1991; Langenheim, 1994), yang mana serangga mempunyai kemoreseptor pada antena, bagian mulut dan tarsus yang dapat membedakan senyawa kimia, seperti larva Pieris brassicae mempunyai reseptor penolak yang distimulasikan pada senyawa alkaloid dan terpenoid. Kehadiran senyawa antimakan yang berupa alkaloid akan merangsang reseptor penolak sehingga menghalangi serangga untuk makan (Mitchell, 1984; Schoonhoven, 1986). Schoonhoven (1982) menyimpulkan bahwa antimakan mungkin merangsang reseptor penolak yang spesifik, merangsang reseptor secara umum, merangsang aktivitas sel dan menghambat yang lainnya, dan menghambat spesifik reseptor penstimulan makan (phagostimulant).

\section{SIMPULAN}

Hasil penelitian dapat disimpulkan bahwa ekstrak aktif antimakan n-heksana batang gayam (Inocarpus fagiferus Fosb.) diduga mengandung senyawa flavonol pyrogallol, senyawa soyasaponin I, senyawa sucrose 2,3,3',4',6-pentaacetate, dan senyawa dengan berat molekul 685,2555 g/mol. Konsentrasi minimal aktif antimakan ekstrak n-heksana batang gayam adalah $3 \%$ dengan aktivitas $44,13 \%$. 


\section{DAFTAR PUSTAKA}

Gershenzon J., Croteau R. 1991. Terpenoids, pp. 165-219.In Rosenthal G.A. and Berenbaum M.R. (eds). Herbivores, Their Interactions with Secondary Metabolites, Vol. 1, The Chemical Participants. Academis Press. New York.

Haji, A.G. Mas'ud, Z. A. Pari, G. 2012. Identifikasi Senyawa Bioaktif Antifeedant dari Asap Cair Hasil Pirolisis Sampah Organik Perkotaan. Jurnal Bumi Lestari. 12(1):1-8.

Hanani, E. 2016. Analisis Fitokimia. Penerbit Buku Kedokteran EGC. Jakarta.

Isman, M.,2002. Insect Antifeedant. Pesticide outlook. The Royal Society of Chemistry.

Langenheim J.H. 1994. Higher Plant Terpenoids: A Phytocentric Overview of Their Ecological Roles. J. Chem Ecol. 20:1223-1271.

Mikolajckzak, K.L. and Weisleder, D. 1988. A Limonoid Antifeedant from Seed of Carapa Procera. J. Nat. Pro. 51(3): 606610.

Mitchell B.K., Sutcliffe J.F. 1984. Sensory Inhibition as A Mechanism of Feeding DeterrenceZ: Effects of Three Alkaloids on Leaf Beetle Feeding. Phys Entomol. 9:57-64.
Pauku Richard L. 2006. Inocarpus fagifer (Tahitian chestnut). Permanent Agriculture Resources. USA.

Ruslan, K. S., Soetarno, dan Sastrodihardjo, S. 1989. Insektisida dari Produk Alami. PAU Bidang Ilmu Hayati, ITB. Bandung.

Schwinger, M., Ehhammer, B., and Kraus, W. 1984. In Natural Pesticides from The Neem Tree (Azadirachta indica A. Juss) and Other Tropical Plants. German Agency for Technical Cooperation. German.

Schoonhoven L.M. 1982. Biological Aspects of Antifeedants. Entomologia Experimentalis et Applicata. 31:57-69.

Schoonhoven L.M. 1986. Perception of Antifeedant by Lepidopterous Larvae,pp. 129-132.In Greenhalgh R. and Roberts T.R. (eds). Pesticide Science and Biotechnology. $6^{\text {th }}$ IUAPC Congress of Pesticide Chemistry Blackwell Scientific. London. 604.

Sukarwa, I. M. 1983. Usada Rare, Proyek Pengadaan Pembinaan dan Pengawasan Obat dan Makanan. Departemen Kesehatan. Provinsi Bali.

Vincent, E. 1995. Sayuran Dunia I: Prinsip Produksi dan Gizi, Edisi II. ITB. Bandung. 